\title{
RECOGNITION OF N-ACETYLGLUCOSAMINE (GLyNAc) AND POLY-N- ACETYLLACTOSAMINE RESIDUES IN VESSELS OF THE RAT PINEAL GLAND
}

\author{
RECONOCIMIENTO DE RESIDUOS DE N-ACETILGLUCOSAMINA (GLyNAc) \\ Y POLI-N-ACETILlactosamina EN VASOS DE LA GLÁNDULA PINEAL DE RATAS
}

\author{
"Mildred Ferreira-Medeiros \& *,**Elenice, M. Correa-Gillieron
}

FERREIRA-MEDEIROS, M. \& CORREA-GILLIERON, E. Recognition of N-acetylglucosamine (GLyNAc) and poly-N-acetyl lactosamine residues in vessels of the rat pineal gland. Int. J. Morphol., 22(4):285-290, 2004.

SUMMARY: Lectins are proteins with binding sites that recognize a specific sequence of sugar moieties in complex glycoconjugates. In the present study the tomato lectin - Lycopersicon esculentum (LEL) (a selective microglial and endothelial marker) has been reported to recognize specific residues of $\mathrm{N}$-acetylglucosamine (GlyNAc) and poly-N-acetyllactosamine. In the pineal gland the biotinylated LEL was used to investigate the appearance of these sugar residues in the structures of the rats during their development and adult life. Our results showed that the binding of LEL occurred exclusively in the material adherents on surface of the endothelia of the vessels in the peripheral and central regions of the gland. An exception can be cited to rats in first postnatal day where the vessels in the central region did not display the LEL-reaction. In all animals studied and, from 3- postnatal day onwards the LEL-reactions could be observed within the central space of pseudo-rosettes also characterizing this space as a vessel.

KEY WORDS: 1. Pineal; 2. Rat; 3. Lectins; 4. Development; 5. Rosettes; 6. Endothelia.

\section{INTRODUCCTION}

In neurohistochemistry the lectins are considered profitable biomarkers of glycoconjugates found in the extracellular space or at the cell surface. Glycoconjugates (glycoproteins and glycolipids) can be considered mediators of differentiation and growth during the maturation of the central nervous system (De Grauw \& Liwricz, 1986). The lectins recognize specific residues of sugars or their nitrogenated forms (Rüdiger, 1998) and the success of lectins in histology lies in the fact that these molecules can be directly conjugated to a label visible by both light and/or electron microscopy (Danguy et al., 1988; Gabius et al., 1998). The tomato lectins - Lycopersicon esculentum (LEL) used in this study has binding sites that recognize specific sugar residues as $\mathrm{N}$-acetyl-glucosamine (GlyNAc) and poly$\mathrm{N}$-acetyl-lactosamine. Specifically in the brain the LEL has been used to as selective microglial marker (Moffett et al., 1997; Dalmau, 2003) but the LEL has been reported to bind to poly- $\mathrm{N}$-acetyl-lactosamine residues in other different cells like as on endothelia (Whyte et al., 1993; Moffett et al., Fakla et al., 1998). This specificity of the LEL in to stain endothelia reinforced the purpose of this paper to study a presumptive pattern for the localization of these residues in the pineal gland vessels during the development as well as in the adults animals through the binding of the biotinylatedLEL.

The mammalian pineal gland $(\mathrm{PG})$ is a neuroendocrine gland responsible by secretion of hormone melatonin ( $\mathrm{N}$ - acetyl-5-methoxytriptamine) (MEL) (Lerner et al., 1958; Pévet, 1983). The importance of MEL has been cited in many studies (Reiter, 1998) and nowadays its important oncostatic role has been showed on hormonedependent tumors (Sanchez-Barcelo et al., 2003). The secretion of MEL has a circadian rhythm and suffers inhibitory effects of the light. The photic stimula reach the PG indirectly via a complex anatomical ways that begins at the retina and converges to the suprachiasmatic nuclei (SCN) through the retinohypothalamic tract (Reuss, 1996). From the SCN the signals goes to pineal via routes which involve the paraventricular nucleus of the hypothalamus, the

\footnotetext{
* Departamento de Histologia y Embriologia, Universidade Federal do Rio de Janeiro, Rio de Janeiro, RJ, Brazil.

** Laboratório de Neurobiologia, Universidade Federal do Rio de Janeiro, Rio de Janeiro, RJ, Brazil.

This work is part of a Master Thesis by Mildred Ferreira Medeiros to fulfill the requirements of the Programa de Pós-Graduação em Morfologia, Universidade do Estado do Rio de Janeiro, RJ, Brazil. CAPES and FAPERJ provided financial support to this work.
} 
intermediolateral nucleus of the spinal cord and finally the superior cervical ganglia that send postganglionic noradrenergic sympathetic fibers to the PG via the so-called nervi conarii (Erlich \& Apuzzo, 1985). Some central nerve fibers reach the PG through the pineal stalk (Garcia-Mauriño et al., 1992).

In rats the gland is surrounded by a capsule (C) of connective tissue from where protruding septa that divided the gland in pseudo-lobules into which are found the main cells types the pinealocytes and glial cells (Calvo \& Boya, 1984; Papasozomenos, 1986; Calvo et al., 1988). About the vascularization of the rat PG it was found that the arterial supply identified on the basis of their endothelial cell imprint patterns (diameter of 20 to $40 \mu \mathrm{m}$ ) comes exclusively from separate branches of the posterior cerebral artery. The venous drainage consisted of short veins (diameter of 40 to $60 \mu \mathrm{m}$ ), all draining directly into the great cerebral vein (Hodde \& Veltman, 1979). Irrespective of obvious species differences in the structures of the vessels in the rat pineal gland the blood capillaries are lined by a fenestrated endothelium and surrounded by wide pericapillary spaces (Taguchi et al., 2000).

\section{MATERIAL AND METHOD}

Forty-four albino Wistar rats (four animals were taken at each age) were kept under normal laboratory conditions (12/12h light/dark cycle) with water and food ad libitum. The animals were sacrificed between 10:0016:00 hours. Birth was considered as postnatal day 0 (PN 0 ) and animal aged at PN 1,3,6,10,15,21,30,45,60,90 and PN 180 were analyzed. The animals deeply anesthetized with ethyl ether were perfused through the left ventricle with $4 \%$ paraformaldehyde in $0,1 \mathrm{M}$ sodium phosphate buffer - PBS (pH 7.4). After, the brains with the pineal glands were postfixed by immersion in the same fixative for $24 \mathrm{~h}$ at $4^{\circ} \mathrm{C}$. The pineal glands were isolated and embedded in paraffin in an oriented position, allowing for both transversal and sagittal sections. The paraffin blocks were sectioned at $7 \mu \mathrm{m}$ thickness. The sections (mounted on poly-L-lysine, Sigma) were deparaffinized, hydrated and, treated with a solution of borax followed by a solution of $1 \%$ bovine serum albumin -BSA in $0.1 \mathrm{M}$ PBS (for overnight at $4{ }^{\circ} \mathrm{C}$ ) in order to block nonspecific binding sites. Endogenous peroxidase was blocked by washing the sections, with a $0.1 \mathrm{M}$ PBS buffer and incubating them in a mixture of methanol absolute containing $15 \% \mathrm{H}_{2} \mathrm{O}_{2}(\mathrm{v} / \mathrm{v})$, for 20 minutes. Subsequently, the sections were rinsed with a 0.1 M PBS buffer (pH 7.4), for 10 minutes and incubated with biotinylated lectin (Tomato lectin - Lycopersicon esculentum) (Kit III - Vector Laboratories) diluted 1:4.000 in $1 \% \mathrm{BSA} / \mathrm{PBS}$, for 1 hour, at room temperature. After washing in PBS for 10 minutes, the sections were treated with avidine-peroxidase complex (Vectastain Kit VPK 6102 mouse IgG - Vector Laboratories), for 30 minutes, followed by another rinse with PBS. The horseradish peroxidase (HRP) histochemistry was performed with $\mathrm{H}_{2} \mathrm{O}_{2}$ and a fresh solution of diaminobenzidine (DAB - Sigma). All sections were washed in TRIS-HCL buffer and distillated water and counterstained with Harry's haematoxylin for 1 minute. After this step the sections were washed (HCL-water), dehydrated in graded alcohols, cleared in xylene and mounted. Control sections were prepared incubating them in $1 \% \mathrm{BSA} / \mathrm{PBS}$ solution without lectin.

\section{RESULTS}

LEL histochemistry resulted in an amorphous reaction product displaying a strong yellowish to brown color (LEL-staining) (Fig. 1). In all ages studied the LELstaining was observed in the endothelia of mostly vessels in the pineal capsules $(\mathrm{C})$, in the central regions of the gland (CR) and, in the peripheral region, which encompasses two subdivisions: the more peripheral layer (PL - underlying the C) and the deep layer (DL - adjacent and under to PL). An exception occurred at PN 1 when LEL staining appeared bordering some vessels of the $\mathrm{C}$, rare ones in parenchyma of the PL and in DL but, none of the vessels appeared in the $\mathrm{CR}$. The features changed quickly at PN 3 where vessels in all regions appeared stained (see insert in Fig. 2A) and, the endothelium of vessels in $\mathrm{C}$ became intensely stained. Between postnatal day 5 to 10 (when the gland increased in size) the LEL-staining was strong in almost all vessels at PN 6 (Fig. 2A) and PN 10. A similar LEL-staining marked all vessels in the others postnatal stages and in the adults (PN 180) (Figs. 2B - PN 15 and Fig. 2C - PN 30). (Figs. 1 and 2).

Additionally, from PN 3 it was possible to distinguish the LEL-staining bordering the inside space of pseudorosettes (Fig.1). The most accurate evidence of rosettes stained was seen at days 60, 90 and 180. The distribution of the LEL-staining within the rosettes became possible to maintain that the central space of rosette is occupied by capillary (Fig. 1). In general, the LEL-staining observed in vessels were particularly strong in the portion of endothelial cells facing to the lumina of the vessel (Fig. 2A) but sometimes the reaction could also seen spreading on the face abluminal of the endothelium. Considering the ability of LEL to recognize GlyNAc and poly-N-acetyllactosamine we 
suggest that some material associated with the endothelia of pineal vessels can have these oligosaccharides residues. A presumptive pattern to the appearance of these residues in rosettes could be seen only from PN 3. In none of ages studied was possible to distinguish another type of cell marked by LEL-reaction, besides of the endothelial cells.

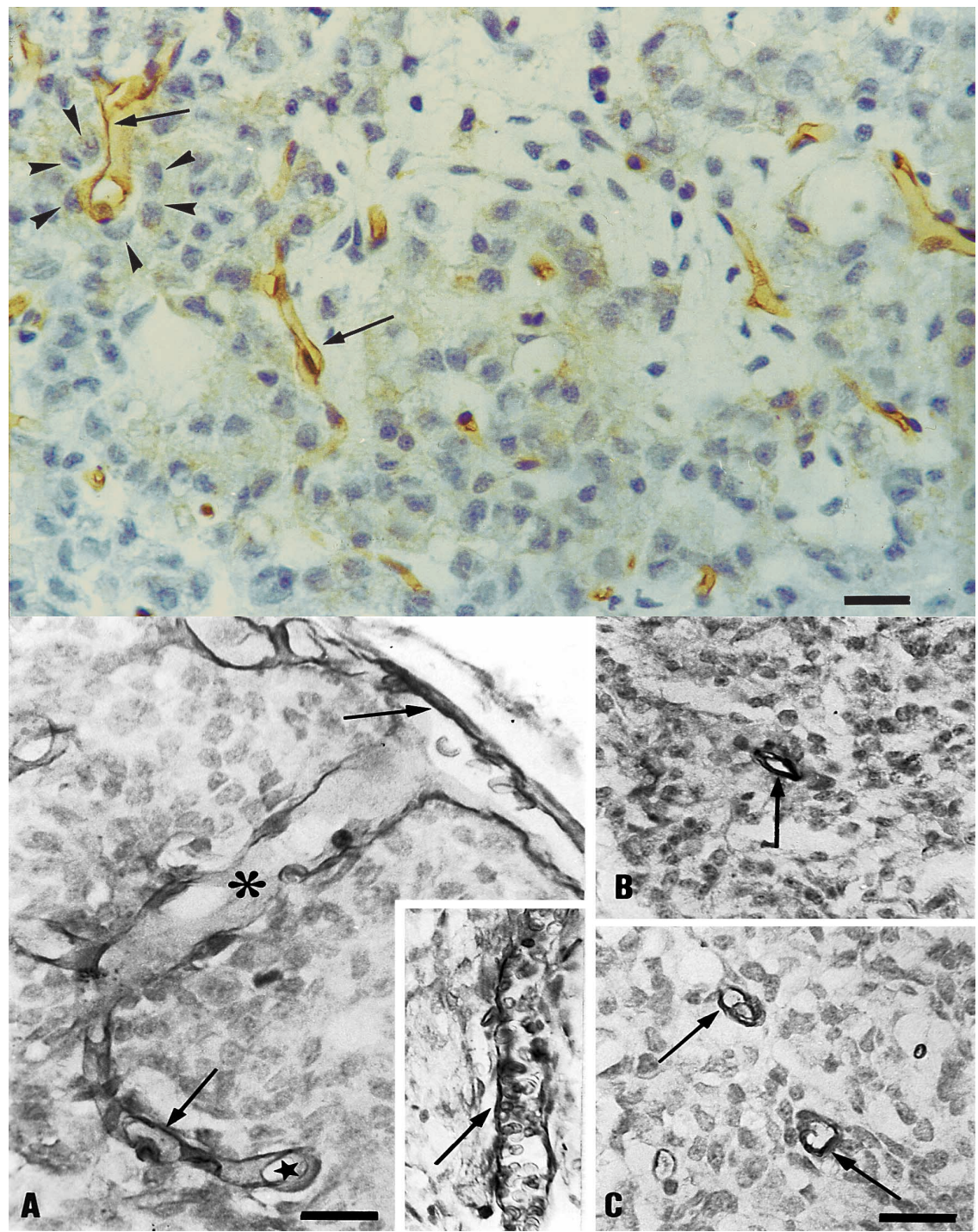

Fig. 1. Adult pineal gland (PN 180). Transversal section. Harri's haematoxylin was used as a nuclear stain. Arrowheads encircle a pseudo-rosette. Thin arrows point the dark line that represent the LEL-staining (that in color pictures appears as an amorphous product displaying a yellowish to brown color) adherents on endothelial lining. Note that the dark line is facing the capillary lumen. Bar: 2,2 mm.

Fig. 2. Photomicrographs of sections of pineal glands: A-PN 6 (sagittal section), the thin arrow points at the black line facing the lumen of vessel. This line represent the LEL staining, which appeared, stained in Figure 1 . The asterisks show the vessel. The stars show a capillary in the deep cortex. PN 3 (sagittal section - see B insert in A); B PN 15 and C - PN 30 (transversal section). Thin arrows point at the LEL staining in the capillaries. Harri's haematoxylin was used as a nuclear stain. A- Bar: $2 \mathrm{~mm}$. B and C - Bar: 2,6 mm.

\section{List of abreviations}

. Bovine albumine serum in sodium phosphate buffer-BSA/PBS

Central regions - CR

Diaminobenzidine - DAB

. Deep layer - DL

Horseradish Peroxidase - HRP

Lycopersicon esculentum lectin - LEL

Mammalian pineal gland - PG

. N-acetylglycosamine - Gly Nac

N-acetyl-5-methoxytriptamine - MEL

. Peripheral layer - PL

. Pineal capsula - C

Postnatal day- PN

Sodium phosphate buffer- PBS

. Suprachiasmatic nuclei-SCN

\section{DISCUSSION}

In rats, pineal gland like retina is immature at birth and develops during the first 2 weeks (Bastianelli \& Pochet, 1995). Intrapineal vessels begin to appear in the pineal of 18-day-embryos and from 19-day-old embryos there is a progressive penetration of connective septa which is more intense dorsally. Capillaries can be seen in this more peripheral and dorsal region following the routes of septa (Calvo \& Boya, 1981). Taking these facts into account, we suggest the lectin-reacted vessels observed in our study at PN 1 (in $\mathrm{C}$ and in the PL and DL regions) may be representing some branches of the initial and immature 
vascular net that accompanied the routes of migration of the connective tissue. Despite the immaturity of the initial stages (PN 1 and 3 - many undifferentiated cells among a few connective tissue) (Calvo \& Boya, 1984) the endothelia of these vessels showed sugar residues capable to bind tomato lectin. Because of the intense endothelial reaction seen at PN 1 in $\mathrm{C}$ we suggest that pineal capsule would be the first region where the endothelial cells are expressing the oligosaccharides residues followed to the peripheral region of the pineal (PL and DL). Perhaps because of the vascular net spreading into the gland at PN 3 the CR was the last region with vessels marked by LEL-staining. Then, a kind of regional pattern (a gradient from periphery to the central regions) to the LEL-staining in the pineal vessels could be inferred to the more immature period of the development (PN 1 to 3), being the capsule the first region that appear LEL-positive and, the central regions is the last one. Perhaps the absence of LEL-positive vascular net at PN 1 in CR could be due an immature state of the vessels in this region to express the ligands to lectin during the angiogenesis, or because at PN 1 the vessels had not reached the CR yet. As from PN 3 onwards the strong LEL-staining was visible in vessels in all pineal regions we suggest a progressive maturation in relation to some material located in the surface of the endothelial lining (displayed by the LEL) possible sugar residues as GlyNAc and poly-N-acetyl-lactosamine. The presence of these glycoconjugates on the surfaces of endothelial cells of gland could have a great importance to the pineal angiogenesis as well as to pineal blood supply, the pineal is a gland highly vascularised (Hogendorf et al., 2001). Thus, these sugar residues (or surface receptors) that bind LEL might have a functional significance in the pineal endothelia.

To Calvo \& Boya (1984) "pseudo-rosettes" were groups of cells radially arranged around a central space (perhaps occupied by cytoplasm) in the periphery of the gland (whereas only some ones were found in the central parenchyma) in the period comprised between PN 15 to 20. We report the occurrence of LEL-staining in the central space of the pseudo-rosettes and this fact permit us to maintain that a vessel occupy the central space of the rosettes and, some material containing poly-acetyllactosamine and GlyNac residues is adherents on the surface of its endothelial cells. These rosettes appeared as early as in PN 3, much earlier than PN 15 and, they were distributed by all regions. The appearance of rosettes also preceded the PN 10, considered by Calvo \& Boya (1984) as the age where clearly differentiated nuclei of pinealocytes. Hence, the rosettes are arrays encountered from PN 3 (an initial and immature stages) onwards. They were not placed preferably in the periphery of the gland neither in adults nor in animals during the development and, the vessels into them can bind LEL.
In spite of the suggestion about a mechanism of parenchyma growth by the formation of rosettes in the embryonic pineal (Calvo \& Boya, 1981) in fact, the meaning of rosettes is still unknown. Even though the solution to this question can be complex our hypothesis is that the pineal rosettes can stand for a functional arrangement of cells around a vessel. Our the most accurate evidence of pseudo-rosettes (and better organized) marked by LEL-staining could be seen at the stages PN 60, 90 and PN 180, a fact that could reinforce our hypothesis about these rosettes to be representing active and functional cellular arrangements around the vessels. We believe that our results showing lectin-reacted endothelium into the rosettes will hopefully solve the doubts about the central space within these structures, principally because the LEL is a biomarker well-known as capable to bind with a high affinity to the endothelium of blood vessels (White et al.; Fakla et al.). Our opinion is supported by our own previous analyses (personal observation) of sections stained with haematoxylin and eosin which allowed us to see indicative features of endothelial cells within the rosettes. The absence of the vessels marked by LEL reaction in small number of the rosettes is a curious fact but could be observed by us. It was impossible to explain and we consider that future investigations are necessary to elucidate this fact.

A fact that might be taken into account is that lectins in order to act on cells bind onto their surfaces, presumably through specific cell surface receptors (Lis \& Sharon, 1977). To Lis \& Sharon the strong binding of lectins to cells occurs sometimes with surface receptors whose affinity for the lectins was higher than of the simple sugars.In the Cuatrecasas (1973) opinion lectins being is multivalent and may possess functionally linked but topographically distinct sites for binding of sugars on one hand, and for attachment to cells on the other. Further experiments may be performed in order to clarify the complete essence of all adhesive components on the surface of the endothelial cells in the pineal gland.

However we are hopeful that our results showing a material containing specific residues (poly-acetyllactosamine and Gly-NAc) in the endothelia of PG vessels (specially in the majority of pseudo-rosettes) during the development and in adults rats will benefit future studies about the physiology of this gland. The polyacetyllactosamine and Gly-NAc are oligosaccharide chains components of many transmembranous glycoproteins and that are particularly important on cell surfaces and in the secretions (Sharon $\&$ Lis, 1998). The observation that in PG residues like these appear only in endothelial cells and since the earlier stages of the development could be associate with the evolutional stages of the vessels and with the regional development of this neuroendocrine gland. 
Acknowledgements: The authors wish to thanks to Christina Maeda Takiya, PhD (Departament of Histology and Embriology, UFRJ, Rio de Janeiro, Brazil) for the lectin-Kit III and Vectastain Kit Reagent and we also wish to thank
Ms. Sônia Oliveira de Souza , M. Sc., (Laboratory of the Cellular Patology, Clementino Fraga Filho Hospital, UFRJ, Rio de Janeiro, Brazil) for help us with the histochemical techniques.

FERREIRA-MEDEIROS, M. \& CORREA-GILLIERON, E. Reconocimiento de residuos de N-acetilglucosamina (Glynac) y poli$\mathrm{N}$-acetillactosamina en vasos de la glándula pineal de ratas. Int. J. Morphol., 22(4):285-290, 2004.

RESUMEN:Las lectinas son proteínas que contienen áreas singulares para el reconocimiento de secuencias de azúcares en los glicoconjugados. La lecitina del tomate Lycopersicon esculentum (LEL) es capaz de reconocer específicamente los residuos de N-acetilglucosamina (Gly-Nac) y poli-N-acetil-lactosamina. Utilizamos la técnica histoquímica para LEL conjugada a la biotina con el propósito de investigar en la glándula pineal de ratones adultos y durante el desarrollo, las estructuras morfológicas capaces de unirse a esta lecitina. Nuestros resultados experimentales mostraron un material de coloración por la LEL, solamente en la superficie de las células endoteliales de todos los vasos sanguíneos y en todas las regiones de la glándula. La excepción ocurrió en los ratones con un día pos-natal (PN1), donde solamente los vasos de la región más periférica de la glándula presentaban coloración marrón amarillenta por la LEL, pero ninguno presentaba esta coloración en la región más central de la glándula. La reacción apareció especialmente en el espacio interno de las pseudo-rosetas, demostrando así que este espacio está, seguramente, representado por un vaso.

PALABRAS CLAVE: 1. Glándula pineal; 2. Rata; 3. Lectinas; 4. Desarrollo; 5. Rosetas; 6. Endotelio.

\section{REFERENCES}

Bastianelli, E. \& Pochet, R. Calbidin, D. 28K, calretinin and S-100 immunoreactivities in rat pineal gland during postnatal development. J. Pineal Res., 18:127-34, 1995.

Calvo, J. \& Boya, J. Embryonic development of the rat pineal gland. Anat. Rec., 200(4):491-500, 1981.

Calvo, J. \& Boya, J. Postnatal development of cell types in the rat pineal gland: light microscopy study. J. Anat., 137:185-95, 1984.

Calvo, J.; Boya, J.; Borregon, A. \& Garcia-Maurino, J. E. Presence of glial cells in the rat pineal : a light and electron microscopic immunohistochemical study. Anat. Rec., 220:424-8, 1988.

Cuatrecasas, P. Interaction of wheat germ agglutinin and concanavalin A with isolated fat cells. Biochemistry, 12(7): 1312-23, 1973.

Danguy, A.; Kiss, R. \& Pastiels, J. L. Lectins in histochemistry: a survey. Biol. Struct. Morphol., 1:93106, 1988.

Dalmau, I.; Vela, J.M.; Gonzalez, B.; Finsen, B. \& Castellano, B. Dynamics of microglia in developing rat brain. $J$. Comp. Neurol., 458(2):44-57, 2003.

De Graw, T. J. \& Liwricz, B.H. Lectins are markers of neuronal migration and differentiation in rat brain. Dev. Neurosci., 8:236-42, 1986.
Erlich, S. S. \& Appuzo, M. L. J. The pineal gland: anatomy, physiology and clinical significance. J. Neurosurg., 63:321-41, 1985.

Fakla, I. A.; Hever, A.; Moinár, J. \& Fischer, J. Tomato lectin labels the $80 \mathrm{KD}$ glycoform of P-glycoprotein in rat brain capillary endotheli and mdr tumor cells. Anticancer Res., 8 (4C):3107-111, 1998.

Gabius, H.J.; Uverzagt, C. \& Kaiser, K. Beyond plant lectin histochemistry : preparation and application of markers for visualize the cellular capacity for protein carbohydrate recognition. Biotech. Histochem., 73(5):263-77, 1998.

Garcia-Mauriño, J. E.; Boya, J.; López-Muñoz, F. \& Calvo, J. L. Immunohistochemical localization of nerve growth factor in the rat pineal gland. Brain Res., 585:255-9, 1992.

Hodde K. C. \& Veltman W. A.The vascularization of the pineal gland (epiphysis cerebri) of the rat. Scan Electron Microsc., 3:369-74, 1979.

Hogendorf, P.; Adamczyk, E. \& Okraszewska, E. Microvascularisation of the pineal gland of the rat. Folia Morphol. (Warsz.) 60(3):191-4, 2001.

Lerner, A. B.; Case, J. D. \& Takahashi, Y. Isolation of melatonin, the pineal gland factor that lightens melanocytes. J. Am. Chem. Soc., 80:2587, 1958. 
Lis, H. \& Sharon, N. Lectins : their chemistry and application to immunology. In The antigen. Michael Sela, Cap.7, V. 4. pp. 429-513, 1977.

Moffet, J. R.; Els, T. ; Espey, M. G.; Walter, S.A. ; Streit, W. J. \& Namboodiri, M.A.A. Quinolate immunoreactivity in experimental rat brain tumors is present in macrophages but not in astrocytes. Experimental Neurology, 144:287-301, 1997.

Papasozomenos, S. C. Astrocytes in the rat pineal gland. $J$. Neuropathol. Exp. Neurol. 45(2):192-4, 1986.

Pévet, P. Is 5-methoxytryptamine a pineal hormone? Psychoneuroendocrinol., 8:61-73 . 1983.

Reiter, R. J. Melatonin and human reprodution. Ann. Med., 30(1):103-8, 1998.

Reuss, S. Components and connections of the circadian timing system in mammals. Cell Tissue Res., 285:353$78,1996$.

Rüdiger, H. Structure and function of plant lectins: In Glycosciences, Status, Status and perspectives (eds. London, Chapman \& Hall), pp. 415-38. London, 1998.

Sanchez-Barcelo, E. J.; Cos, F. \&Mediavilla, M. D. Melatonin and mammary cancer: a short review. Endocr. Relat. Cancer, 10(2):153-9, 2003.
Sharon, N. \& Lis, S. Carbohydrate in cell recognition in cell recognition molecules. Science, 2(46):227-34, 1998.

Taguchi, T.; Kosaka, M.; Murakami, S.; Ohtsuka, A. \& Murakami, T. Intensely negative charged pericapillary spaces in the rat pineal gland. Arch. Histol. Cytol., 63(5):485-94, 2000.

White, J.; Garrot, J. \& Binnis, R. M. Distribution of saccharide in pig lymphonode high endothelial venules and associated lymphocytes visualize using fluorescent lectins and confocal microscopic. Histochem. J., 25(10):726-34, 1993.

Correspondence to:

Prof. Dra. Elenice Maria Correa-Gillieron

Departamento de Histologia e Embriologia

Centro de Ciências da Saúde,

$I C \mathcal{B}$, Bloco F2, Sala 23,

Universidade Federal do Rio de Janeiro

CEP 21941-590

Rio de Janeiro, $R$

BRAZIL

E-mail: corgillieron@ufrj.br

Received: 16-08-2004

Accepted: 13-10-2004 